\title{
Urinary kallikrein excretion in Type 1 (insulin-dependent) diabetes mellitus
}

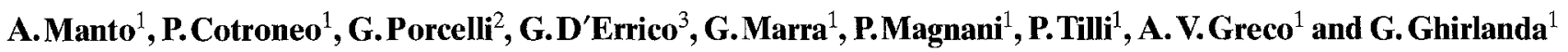 \\ ${ }^{1}$ Istituto Clinica Medica, Rome, Italy \\ ${ }^{2}$ CNR Chimica del Recettore, Rome, Italy \\ ${ }^{3}$ Medicina Nucleare Università Cattolica S. Cuore, Rome, Italy
}

\begin{abstract}
Summary. Kidney haemodynamics appear to change after the early phases of diabetic nephropathy: increases in glomerular filtration rate and in renal plasma flow have been widely reported, while kidney size is increased. As the renal kallikrein-kinin system has been demonstrated to regulate kidney blood circulation, we have evaluated the excretion of urinary kallikrein in 87 Type 1 (insulin-dependent) diabetic patients with and without hyperfiltration. Urinary kallikrein excretion was measured in 24-h urine collections. The esterolytic activity was determined by fluorimetric assay. The excretion of urinary kallikreins was significantly higher in hyperfiltering patients $(472 \pm 125$ esterase units $/ 24 \mathrm{~h})$ than in normofiltering (168 \pm 77 esterase units/24 h) and control sub-
\end{abstract}

jects $(151 \pm 39$ esterase units/24 h), $p<0.001$. Furthermore, we observed a positive correlation between urinary kallikrein excretion and glomerular filtration rate $(r=0.785)$. These data suggest that variations of kallikrein and kinin concentrations may play a role in the alteration of renal haemodynamics in Type 1 diabetes. It is possible that the kinin-kallikrein system, the renin-angiotensin system and the prostaglandins may interact to determine the haemodynamic alterations which are present in the diabetic disease.

Key words: Diabetic nephropathy, hyperfiltration, Type 1 (insulin-dependent) diabetes mellitus, urinary kallikrein excretion.
One-third of all patients with Type 1 (insulin-dependent) diabetes mellitus are at risk of developing a nephropathic complication $[1,2]$. In the early phases of nephropathy these subjects show an increased glomerular filtration rate (GFR), elevated renal plasma flow (RPF) and increased kidney size [3-8]. Factors other than blood glucose levels such as atrial natriuretic factor $[9,10]$, vasodilatory prostaglandins [11] and kallikrein-kinin system could be associated with this circulatory alteration.

The renal kallikrein-kinin system has been shown to regulate kidney haemodynamics with a paracrine mechanism. Renal (glandular) kallikreins are a subfamily of serine-proteases which liberate potent kinin peptides from kininogen substrates through limited proteolysis. The renal kallikrein-kinin system has been shown to regulate kidney haemodynamics [12-14] by modulating such parameters as blood pressure, blood flow, renal vascular resistance and capillary permeability [15]. Decreased kallikrein excretion in Type 2 (non-insulin-dependent) diabetic patients with hypertension and nephropathy $[16,17]$ and elevated urinary kallikrein concentration in patients with poorly-controlled Type 1 diabetes has been reported [18]. Moreover, different reports have shown that untreated streptozotocin diabetic rats show a reduced synthesis and excretion of active renal kallikrein [19-21].

Interactions between the renal kallikrein-kinin system, prostaglandins and the renin-angiotensin system have been described [22-26]. The relationship between urinary kallikrein excretion and hyperfiltration in incipient diabetic nephropathy has not yet been clearly established. The aim of our study is to evaluate the behaviour of urinary excretion of kallikrein in two groups of Type 1 diabetic patients with and without glomerular hyperfiltration.

\section{Patients and methods}

\section{Patients}

Eighty-nine Caucasian Type 1 diabetic patients without hypertension (blood pressure $<160 / 90 \mathrm{~mm} \mathrm{Hg}$ ), renal disease or any diabetic complications were recruited: of these 78 were normofiltering (group A) while 11 showed an increased GFR (group B); a group of 20 healthy subjects, matched for age and sex, with no family history of hypertension, served as controls. Each subject gave informed consent. The study was performed according to the Helsinki Declaration. The composition of usual patient diet was assessed by analysis of 3-day weighed food records. The test was performed in the morn- 
Table 1. Age, sex, duration of Type 1 diabetes, blood pressure, BMI, creatinine, $\mathrm{BUN}, \mathrm{HbA}_{\mathrm{tc}}$, overnight albumin excretion rate and creatinine clearance in control subjects, normofiltering (group A) and hyperfiltering (group B) diabetic subjects

\begin{tabular}{|c|c|c|c|}
\hline & $\begin{array}{l}\text { Control } \\
\text { subjects }\end{array}$ & Group A & Group B \\
\hline Age (years) & $29 \pm 7$ & $30 \pm 9$ & $30 \pm 10$ \\
\hline Sex (male/female) & $12 / 8$ & $34 / 44$ & $7 / 4$ \\
\hline $\begin{array}{l}\text { Duration diabetes } \\
\text { (years) }\end{array}$ & & $12.5 \pm 7.5$ & $14 \pm 2$ \\
\hline $\begin{array}{l}\text { Systolic blood } \\
\text { pressure }(\mathrm{mm} \mathrm{Hg})\end{array}$ & $110 \pm 10$ & $115 \pm 8$ & $110 \pm 10$ \\
\hline $\begin{array}{l}\text { Diastolic blood } \\
\text { pressure }(\mathrm{mm} \mathrm{Hg})\end{array}$ & $70 \pm 5$ & $65 \pm 10$ & $70 \pm 10$ \\
\hline $\mathrm{BMI}\left(\mathrm{kg} / \mathrm{m}^{2}\right)$ & $22 \pm 1$ & $21 \pm 2$ & $20 \pm 2$ \\
\hline Creatinine $(\mu \mathrm{mol} / \mathrm{l})$ & $61 \pm 7.6$ & $61 \pm 15$ & $68 \pm 7.6$ \\
\hline $\mathrm{BUN}(\mathrm{mmol} / \mathrm{l})$ & $10.7 \pm 2$ & $11.8 \pm 2.8$ & $10 \pm 2$ \\
\hline $\mathrm{Hb}_{\mathrm{lc}}(\%)$ & $3.8 \pm 0.5$ & $7 \pm 1.3$ & $6.3 \pm 1.4$ \\
\hline $\operatorname{AER}\left(\mu \mathrm{g} / \mathrm{min}^{-1}\right)$ & $10 \pm 10$ & $10 \pm 9$ & $6.6 \pm 4.4$ \\
\hline $\begin{array}{l}\text { Creatinine clearance } \\
(\mathrm{ml} / \mathrm{min})\end{array}$ & $110 \pm 8$ & $110 \pm 10$ & $126 \pm 46$ \\
\hline
\end{tabular}

BMI, Body mass index; BUN, blood urea nitrogen; AER, albumin excretion rate

ing following a standard light breakfast $(150 \mathrm{~g}$ milk with $20 \mathrm{~g}$ of bread) for all groups.

\section{Methods}

To simultaneously evaluate GFR and RPF, a single $i . v$. bohs injec-

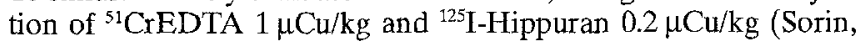
Saluggia, Italy) was calibrated and made up to $10 \mathrm{ml}$ with $\mathrm{NaCl}$ $(0.9 \%)$, which was then administered $90 \mathrm{~min}$ after breakfast. Blood plasma was taken at 5, 10,20,30,44, 50,60,80,120,180,240 min after the injection. During the test the patients were kept euglycaemic and were in the supine position. Subjects were asked to avoid smoking during the study. GFR and RPF were measured as the clearance of the isotopes under the assumption that all the tracer is excreted, that the only route is renal and that the total amount of tracer excreted will be equal to the quantity injected.

The plasma clearance measurement techniques may be classified as follows: 1) For GFR: double exponential analysis utilized blood samples at $5,10,20$ and $80,120,180,240$ min to obtain the two slopes $\lambda$ and $\lambda 2$. The monoexponential analysis utilized onty later plasma samples taken at $80,120,180,240 \mathrm{~min}[27,28]$. The method from value distribution measurement utilized only the one taken at $180 \min [29] .2)$ For RPF: the double exponential analysis used all blood samples taken at 5,10,20 and 44, 50,60 min. The monoexponential analysis utilized samples taken at $44,50,60 \mathrm{~min}$. The method from value distribution measurement utilized the sample at $44 \min$.

We preferred to use the double exponential analysis because it is very reliable. In our laboratory the values of GFR and RPF in normal subjects range from 80 to $130 \mathrm{ml} \cdot \mathrm{min}^{-1} \cdot 1.73 \mathrm{~m}^{2}$ and from 500 to $650 \mathrm{ml} \cdot \mathrm{min}^{-1} \cdot 1.73 \mathrm{~m}^{2}$ respectively. Patients with GFR over $135 \mathrm{ml} \cdot \mathrm{min}^{-1} \cdot 1.73 \mathrm{~m}^{2}$ were considered hyperfiltering. Blood urea nitrogen was determined by Berthelot reaction, serum, urinary creatinine were measured by a modification of the Jaffé method with alkaline nitrate [30], glycated haemoglobin $\left(\mathrm{HbA}_{1 \mathrm{c}}\right)$ by the HPLC method, albuminuria by radioimmunoassay (Albumin DA; Sclavo, Siena, Italy). Systolic and diastolic blood pressure were evaluated twice by Random-Zero mercury sphygmomanometer, by the same observer.

Urinary kallikrein excretion was measured in 24 -h urine collections. Urine samples were stored under toluene at $4^{\circ} \mathrm{C}$ until assayed. The esterolytic activity was determined by modification of the Morita method [31] using L-propyl-L-phenylanil-L-arginil-7-amido4-methylcoumarine-ester (Bachem; Feinchemikalien, AG Bubendorf, Switzerland) as substrate. Fluorimetric measurements were carried out with excitation at $380 \mathrm{~nm}$ and emission at $460 \mathrm{~nm}$ in a Perkin-Elmer fluorimeter. One esterase unit (EU) was defined as the amount of enzyme which hydrolyses $10 \mu \mathrm{mol}$ of methylcoumarine/min at $\mathrm{pH} 8.0$ and $37^{\circ} \mathrm{C}$ in a standard assay.

\section{Statistical analysis}

Data are expressed as the mean \pm SEM. Differences between the three groups were assessed by univariate analysis of variance (ANOVA) with subsequent $t$-test applied where the differences were significant. Correlation was determined by linear regression analysis (performed with the computer programme Statview 512 Apple). Differences and correlations were considered significant at $p<0.05$.

\section{Results}

Our data showed no significant differences in age, sex and duration of diabetes in groups $\mathrm{A}$ and $\mathrm{B}$ (Table 1). The value of $\mathrm{HbA}_{1 \mathrm{c}}$ in normofiltering and hyperfiltering patients were similar $(7 \pm 1.3 \%$ vs $6.3 \pm 1.4 \% ; p=\mathrm{NS})$. Albumin excretion rate was $10 \pm 9 \mu \mathrm{g} / \mathrm{min}$ (range 0.2 $24 \mu \mathrm{g} / \mathrm{min}$ ) in group A and $6.6 \pm 4.4 \mu \mathrm{g} / \mathrm{min}$ (range 1.0 $15 \mu \mathrm{g} / \mathrm{min}$ ) in group $\mathrm{B}, p=\mathrm{NS}$ (Table 1 ).

The excretion rate of urinary kallikreins was $151 \pm 39$ EU. $24 \mathrm{~h} \cdot$ incubation min in control subjects, $168 \pm 77$ EU. $24 \mathrm{~h} \cdot$ incubation min in normofiltering patients and $472 \pm 125 \mathrm{EU} \cdot 24 \mathrm{~h} \cdot$ incubation min in hyperfiltering patients. The excretion of urinary kallikreins was significantly higher in hyperfiltering patients than in normofiltering and control subjects; $p<0.001$ (Fig. 1).

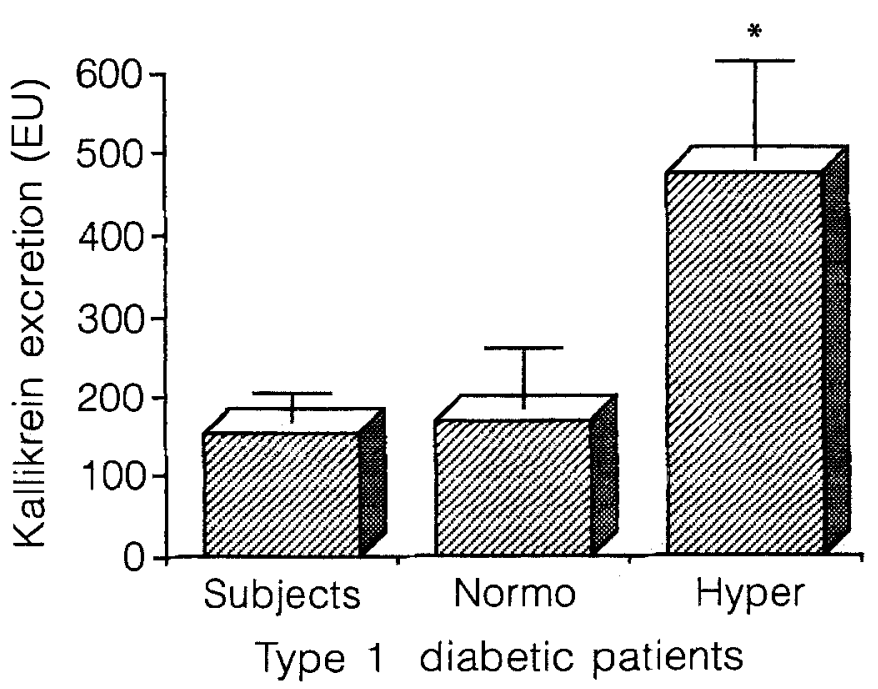

Fig. 1. Urinary kallikrein excretion in control subjects $(n=20)$, normofiltering Type 1 diabetic patients $(n=78)$ and hyperfiltering Type 1 diabetic patients $(n=11)$. EU, esterase units. * $p<0.001$ 

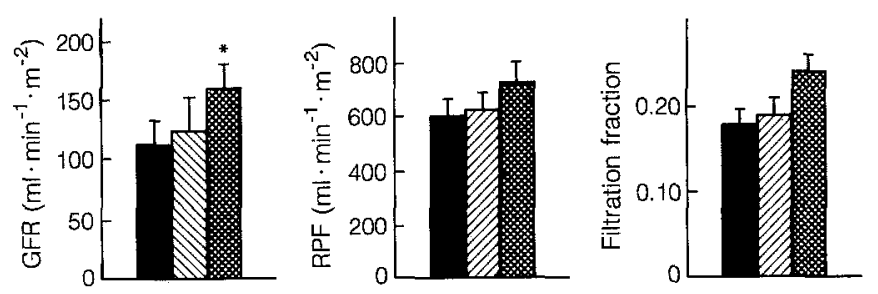

Fig. 2. Glomerular filtration rate (GFR), renal plasma flow (RPF) and filtration fraction in normal subjects ( $)$, in normofiltering Type 1 diabetic patients (缕) and in hyperfiltering Type 1 diabetic patients (r) $* p<0.001$

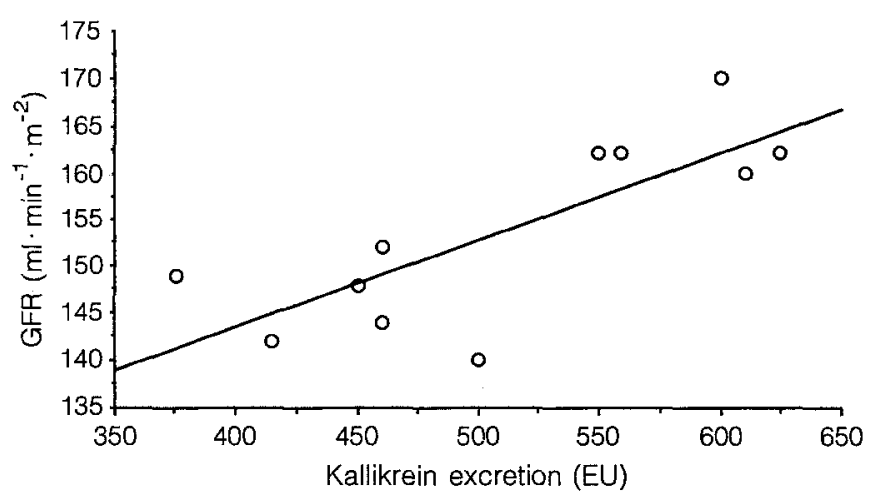

Fig. 3. Correlation between urinary kallikrein excretion (esterase units, EU/24 h) and glomerular filtration rate (GFR) (ml $\mathrm{min}^{-1}$. $\left.\mathrm{m}^{-2}\right)$ in Type 1 diabetic patients with hyperfiltration $(n=11)$ (group B); $(r=0.785, p<0.04$ )

The mean of GFR in hyperfiltering patients was $161 \pm 19 \mathrm{ml} \cdot \mathrm{min}^{-1} \cdot \mathrm{m}^{-2}(p<0.001)$ compared to $125 \pm$ $26 \mathrm{ml} \cdot \mathrm{min}^{-1} \cdot \mathrm{m}^{-2}$ in normofiltering Type 1 diabetic patients and $112 \pm 20 \mathrm{ml} \cdot \mathrm{min}^{-1} \cdot \mathrm{m}^{-2}$ in control subjects. Although the RPF tended to be higher in hyperfiltering patients, neither the RPF nor the filtration fraction (FF) significantly increased (Fig. 2). Furthermore, we observed a positive correlation, in hyperfiltering patients, between urinary kallikrein excretion and GFR $(r=0.785, p<0.04)$ (Fig. 3). There was no correlation between excretion of urinary kallikrein and each of the following parameters: albumin excretion rate $(r<0.022)$, and creatinine clearance $(r<0.025), \mathrm{HbA}_{1 \mathrm{c}}(r<0.026)$, duration of diabetes $(r<0.09)$ in hyperfiltering Type 1 diabetic patients. Furthermore no correlation was observed in normofiltering Type 1 diabetic patients between kallikrein excretion and all parameters mentioned above.

\section{Discussion}

This study shows that diabetic subjects with glomerular hyperfiltration have increased excretion of urinary kallikrein, compared to diabetic patients with normal GFR or control subjects. Our data are in accordance with the study of Harvey et al. [32] that showed an increase in renal active kallikrein excretion in Type 1 diabetic patients with hyperfiltration.

Previously Harvey et al. [21] observed a rise in the concentration of both urinary and renal kallikreins in strepto- zotocin-induced diabetic rats with moderately hyperglycaemic values and increased GFR. Conversely, Mayfield et al. [18] showed that kallikrein excretion is increased in patients with poorly-controlled Type 1 diabetes; while strict glycaemic control decreases urinary kallikrein excretion. This observation could be explained by the direct effect of hyperglycaemia on glomerular hyperfiltration. Nevertheless all our hyperfiltering and normofiltering Type 1 diabetic patients were in good metabolic control with similar $\mathrm{HbA}_{1 \mathrm{c}}$ values.

The observation that injection of aprotinin [21, 33, 34], a protease inhibitor, reduces GFR and RPF in rats, suggests a further correlation between kallikrein activity and haemodynamic alterations. Although aprotinin does not specifically inhibit the kallikreins, other proteases known to be inhibited by aprotinin have no effect on renal activity suggesting that the effect of aprotinin is due to a direct kallikrein inhibition.

Levy et al. [35] found a direct relationship between RPF and urinary kallikrein excretion in humans; many studies in animals also suggest a direct relationship between the renal kallikrein-kinin system and renal blood flow [12-14]. In our study we found a slight increase of RPF and FF in hyperfiltering Type 1 diabetic patients. Furthermore, the urine volume did not change in all three groups studied excluding a washout effect secondary to GFR changes.

Moreover, urinary kallikrein excretion is related to protein intake: an increase in renal kallikrein synthesis and excretion with a rise in GFR and RPF has been noticed in non-diabetic and in streptozotocin-diabetic rats with high protein intake [36]. On the other hand several studies have found that GFR and RPF are reduced in rats kept on a protein-restricted diet in contrast to rats fed with high-protein diet [37-40]; such parameters are also reduced in humans receiving a low protein-diet [41]. Mauer et al. [42] reported that increasing protein in the diet from $20 \%$ to $50 \%$ raised both GFR and RPF in normal rats. In our study the diabetic hyperfiltering patients had a protein intake lower than $19 \%$ similar to normofiltering patients; $30 \%$ of the total amount of protein present in our usual diet derived from vegetables. According to Jones et al. $[43,44]$ a meal of vegetable proteins has no effect on kidney function and no abnormalities in renal haemodynamics have been reported in vegetarians [45].

It was shown that in rats [46] and in normal man [47] on chronic high and low sodium diets urinary kallikrein excretion was positively correlated to urinary volumes but not to sodium excretion [46]. Although the intake of sodium was not controlled in our patients, analysis of the food record showed no significant differences in dietary amount of sodium in the three groups (data not shown). There was no significant change in urinary volume and sodium excretion between normofiltering and hyperfiltering Type 1 diabetic patients. In conclusion we observed an increased kallikrein excretion in Type 1 diabetic hyperfiltering patients, positively correlated to GFR. The increase in kallikrein excretion may represent a marker of the early phase of diabetic nephropathy.

Further investigations will be required to study the synthesis and secretion of kallikrein in the different phases of 
diabetic nephropathy and to evaluate the role of the kallikrein-kinin system in the pathogenesis of this complication.

Acknowledgement. This work was supported by a grant from the C.N.R. (Italy).

\section{References}

1. Andersen AR, Christiansen JS, Andersen JK, Kreiner S, Deckert T (1983) Diabetic nephropathy in type 1(insulin-dependent) diabetes: an epidemiological study. Diabetologia 25:496-501

2. Krowleski AS, Warram JH, Christlieb AR, Bunsick ET, Kahn CR (1985) The changing natural history of nephropathy in type 1 diabetes. Am J Med 78:785-794

3. Parving H-H, Smidt UM, Friisberg B, Bonnevie Nielsen V, Andersen AR (1981) A prospective study of glomerular filtration rate and arterial blood pressure in insulin-dependent diabetes with diabetic nephropathy. Diabetologia 20:457-461

4. Mogensen CE, Schmitz A, Christiensen CK (1988) Comparative renal pathophysiology relevant to type 1 diabetic patients. Diabetes Metab Rev 4: 453-483

5. Viberti GC (1988) Recent advances in understanding the mechanism and natural history of diabetic renal disease. Diabetes Care 11: 3-9

6. Mogensen CE (1971) Glomerular filtration rate and renal plasma flow in short-term and long-term juvenile diabetes mellitus. Scand J Clin Lab Invest 28:91-100

7. Mogensen CE, Steffes MW, Deckert T, Christiansen JS (1981) Functional and morphological renal manifestations in diabetes mellitus. Diabetologia 21: 89-93

8. Christiansen JS, Gammelgaard J, Frandsen M, Parving $\mathrm{HH}$ (1981) Increased kidney size, glomerular filtration rate and renal plasma flow in short-term insulin dependent diabetics. Diabetologia 20: 451-456

9. Ortola FV, Ballerman BJ, Anderson S, Mendez RE, Brenner BM (1987) Elevated plasma atrial natriuretic peptides levels in diabetic rats: potential mediators of hyperfiltration. J Clin Invest 80: 670-674

10. Perico N, Benigni A, Gabanelli M et al. (1992) Atrial natriuretic peptide and prostacyclin synergistically mediated hyperfiltration and hyperperfusion on diabetic rats. Diabetes 41:533-538

11. Craven PA, Caines MA, De Rubertis FR (1987) Sequential alteration in glomerular prostaglandins and thromboxane synthesis in diabetic rats: relationship to the hyperfiltration of early diabetes. Metabolism 36: 95-103

12. Barajas L, Powers K, Carretero OA, Scicli AG, Inagami T (1986) Immunocytochemical localization of renin and kallikrein in the rat renal cortex. Kidney Int 29: 965-970

13. Edwards RM (1985) Response of isolated renal arterioles to acetylcholine, dopamine, and bradykinin. Am J Physiol 248: F183-F189

14. Schnerman J, Briggs JP, Schubert G, Marin-Grez M (1984) Opposing effects of captopril and aprotinin on tubuloglomerular feedback responses. Am J Physiol 247: F912-F918

15. Scicli AG, Carrettero OA (1980) Renal kallikrein-kinin system. Am J Physiol 238: F247-255

16. Baba T, Murabayashi S, Ishizaki T, Ido Y, Aoyagi K, Takeba K (1986) Renal kallikrein in diabetic patients with hypertension accompanied by nephropathy. Diabetologia 29: 162-167

17. Greco AV, Porcelli G, Di Iorio M, Ranieri M, D'Acquarica L, Ranalli L (1979) Altered urinary excretion of human kininase activity in hypertension. Adv Exper Med Biol 120B: 645-649

18. Mayfield RK, Margolius HS, Levine JH, Wohltmann HJ, Loadholt CB, Colwell JA (1984) Urinary kallikrein excretion in insulin-dependent diabetes mellitus and its relationship to glycaemic control. J Clin Endocrinol Metab 59: 278-286
19. Mayfield RK, Margolius HS, Bailey GS et al. (1985) Urinary and renal tissue kallikrein in the streptozotocin-diabetic rat. Diabetes 34: 22-28

20. Jaffa AA, Miller DH, Bailey GS, Chao J, Margolius HS, Mayfield RK (1987) Abnormal regulation of renal kallikrein in experimental diabetes: effects of insulin on prokallikrein synthesis and activation. J Clin Invest 80: 1651-1659

21. Harvey HJ, Jaffa AA, Margolius HS, Mayfield RK (1990) Renal kallikrein and haemodynamic abnormalities of diabetic kidney. Diabetes 39: 299-304

22. Uglesity A, Kreisberg JI, Levine L (1983) Stimulation of arachidonic acid metabolism in rat kidney mesangial cells by bradykinin, antidiuretic hormone and their analogues. Prostaglandins Leukot Essent Fatty Acids 10: 83-93

23. Hura CE, Kunau RT (1988) Angiotensin II stimulated prostaglandin producton by canine afferent arterioles. Am J Physiol 254: F734-F736

24. Garcia R, Thibault G, Hamet P, Gutkonska J, Cantin M, Genest $J(1985)$ Effect of atrial natriuretic factor on kallikrein and cyclic GMP in renovascular hypertensive rat. Clin Exp Hypertens (A) 7:1597-1618

25. Beierwaltes WH, Prada J, Carretero OA (1985) Kinin stimulation of renin release in isolated rat glomeruli. Am J Physiol 17: F757-F761

26. Beierwaltes WH, Prada J, Carretero OA (1985) Effect of glandular kallikrein on renin release in isolated rat glomeruli. Hypertension 7: 27-31

27. Garnett ES, Parson V, Veall N (1967) Measurements of glomerular filtration rate in a man using a ${ }^{51} \mathrm{Cr}$ edetic acid complex. Lancet I: $818-822$

28. Lindgardh G (1972) Renal clearance investigations with ${ }^{51} \mathrm{Cr}$ EDTA and ${ }^{125}$ I-Hippuran. Scand J Urol Neprol 6: 63-73

29. Constable AR, Hussein MM, Albrecht MP, Joekes AM (1980) Renal clearance determined from single plasma samples. In: Hollemberg NK, Lange R (eds) Radionuclide in nephrology, Georg Thieme Verlag, Stuttgart, New York pp 62-66

30. Chaney AC, Merbach EP (1962) Modified reaction for determination of urea and ammonia. Clin Chem 8:130-132

31. Morita T, Kato H, Iwanaga S, Takada K, Kimura T, Sakakibara S (1977) New fluorogenic substrates for $\alpha$-thrombin, factor Xa, kallikreins and urokinase. J Biochem 82: 1495-1498

32. Harvey JN, Edmundson AW, Jaffa AA, Martin LL, Mayfield RK, (1992) Renal excretion of kallikrein and eicosanoids in patients with type 1 (insulin-dependent) diabetes mellitus. Relationship to glomerular and tubular function. Diabetologia 35: $857-862$

33. Johnston PA, Bernard DB, Perrin NS, Arbeit L, Lieberthal W, Levinski NG (1981) Control of rat renal vascular resistance during alterations in sodium balance. Circ Res 48: 728-733

34. Seto S, Kher V, Scicli AG, Beierwaltes WK, Carrettero OA (1983) The effect of aprotinin (a serine protease inhibitor) on renal function and renin release. Hypertension 5:893-899

35. Levy SB, Lilley JJ, Frigon RP, Stone RA (1977) Urinary kallikrein and plasma renal activity as determinants of renal blood flow. The influence of race and dietary sodium intake. J Clin Invest 60: $129-138$

36. Jaffa AY, Harvey JN, Sutherland SE, Margolius HS, Mayfield RK (1989) Renal kallikrein responses to dietary protein: a possible mediator of hyperfiltration. Kidney Int 36: 1003-1010

37. Hostetter TH, Meyer TW, Rennke HG, Brenner BM (1986) Chronic effects of dictary protein in the rat with intact and reduced renal mass. Kidney Int 30: 509-517

38. Zatz R, Meyer TW, Rennke HG, Brenner BM (1985) Predominance of haemodynamic rather than metabolic factors in the pathogenesis of diabetic glomerulopathy. Proc Natl Acad Sci USA 82: 5963-5967

39. Ichikawa I, Purkerson ML, Klahr S, Troy GL, Martinez-Maldonato M, Brenner BM (1980) Mechanism of reduced glomerular filtration rate in chronic malnutrition. J Clin Invest 65:982-988

40. Fernandez-Repollet E, Tapia E, Martinez-Maldonato M (1987) Effect of angiotensin converting enzyme inhibition on altered 

renal haemodynamics induced by low protein diet in the rat. $\mathrm{J}$ Clin Invest 80: 1045-1049

41. Pedersen MM, Mogensen CE, Jorgensen FS, Moller B, Lykke G, Pedersen O (1989) Renal effect from limitation of high dietary protein in normoalbuminuric diabetic patients. Kidney Int 27 : S115-S121

42. Mauer SM, Steffes MW, Azzar S, Brown DM (1989) Effect of dietary protein content in streptozotocin diabetic rats. Kidney Int 35: 48-59

43. Jones G, Lee K, Swaminathan R (1985) Glomerular filtration response to acute protein load. Lancet II: 838

44. Jones G, Lee K, Swaminathan R (1987) The effect of dietary protein on glomerular filtration rate in normal subjects. Clin Nephrol 27:71-75

45. Wiseman MJ, Hunt R, Goodwin A, Gross JL, Keen H, Viberti GC (1987) Dietary compostition and renal function in healthy subjects. Nephron 46: 37-42
46. Marin-Grez M (1974) The influence of antibodies against bradykinin on isotonic saline diuresis in the rat. Pflugers Arch 350: 231-239

47. Margolius HS, Horwitz D, Geller RG et al. (1974) Urinary kallikrein excretion in normal men. Relationships to sodium intake and sodium-retaining steroids. Circ Res 35: 812-819

Received: 28 August 1992

and in revised form: 21 December 1992

Prof. G. Ghirlanda

Istituto Clinica Medica

Università Cattolica del Sacro Cuore

Largo A. Gemelli 8

I-00168 Roma

Italy 